Reprod. Nutr. Dévelop., 1983, 23 (2 A), 259-271.

\title{
Effect of microflora and lactose on the absorption of calcium, phosphorus and magnesium in the hindgut of the rat
}

\author{
Claude ANDRIEUX, E. SACOUET
}

Laboratoire des Animaux sans Germes, C.N.R.S., I.N.R.A., 78350 Jouy-en-Josas, France.

Summary. For 4 weeks, 3-month old germfree (GF) and conventional (CV) rats were given a semi-synthetic diet sterilized by irradiation with or without $10 \%$ of lactose. During the 5th week, $0.2 \%$ of titanium oxide $\left(\mathrm{TiO}_{2}\right)$ was added to the diet and the rats were killed at regular intervals throughout the light/dark cycle. The patterns of $\mathrm{TiO}_{2}$ and ${ }^{45} \mathrm{Ca}$ excretion were similar, indicating that $\mathrm{TiO}_{2}$ was a good marker of unabsorbed calcium transit. The apparent absorption coefficient of calcium, magnesium and phosphorus was determined in the ileum, caecum, large intestine and faeces by the mineral/ $/ \mathrm{TiO}_{2}$ ratio. The effects of microflora and lactose varied with the mineral and the digestive tract level studied.

- In the small intestine, microflora had no effect on the apparent absorption of calcium and magnesium but did have an unfavorable influence on phosphorus absorption. Lactose increased calcium and magnesium absorption, and this increase was similar in GF and $\mathrm{CV}$ rats, but lactose had a favorable effect on phosphorus absorption only in CV rats.

- In the caecum, microflora had an unfavorable effect on the apparent absorption of calcium and magnesium and a favorable effect on phosphorus absorption. The ingestion of lactose reduced calcium and magnesium absorption in the caecum of GF rats and phosphorus absorption in the caecum of $\mathrm{CV}$ animals.

- In the colon, mineral absorption was not significant in either CV or GF rats receiving the lactose-free diets. Lactose ingestion caused the absorption of calcium, magnesium and phosphorus to rise significantly only in GF rats. This absorption contributed to the stronger effect of lactose on total calcium and phosphorus absorption in GF rats.

\section{Introduction.}

We reported previously (Andrieux, Sacquet and Guéguen, 1982) that lactose increases the absorption and retention of calcium and phosphorus more in adult germfree (GF) than in adult conventional (CV) rats. In the voluminous caecum of GF rats, lactose increases the amount of calcium that is soluble and, hence, that which is liable to be absorbed. This observation led us to suppose that there might be calcium absorption in the hindgut of GF rats which would explain the differences in apparent absorption between GF and $\mathrm{CV}$ rats both fed a lactose diet. 
The present paper reports a study of the apparent absorption coefficient of calcium, magnesium and phosphorus in the ileum, caecum, colon and faeces of GF and $\mathrm{CV}$ rats. We used titanium oxide $\left(\mathrm{TiO}_{2}\right)$, an unabsorbable marker (Fournier, 1950), and first gave it in the diet long enough to establish an equilibrium between its ingestion and faecal excretion. Apparent absorption of the minerals was determined by measuring the mineral/marker ratio throughout the light/dark cycle. This paper assesses the value of the method and the results obtained.

\section{Material and methods.}

Animals and diet. - We used GF and CV rats of Fischer strain 344 that had been fed a commercial diet. At 3 months of age, they were fed a semi-synthetic diet with $10 \%$ of lactose (L) or without (LO) (table 1). At 15 weeks, they were put into metabolism crates and at 16 weeks were fed the $L$ or $L O$ diet to which we had added $0.2 \%$ of $\mathrm{TiO}_{2}$. The diets, sterilized by gamma irradiation at 40 kilo-Gray in vacuum-sealed plastic bags, were given ad libitum in the form of a paste containing $60 \%$ of water.

\section{Method used for measuring apparent absorption.}

Rationale. - The method we used to measure apparent absorption of minerals was derived from a classical method for studying net nutriment utilization (Kotb and Luckey, 1972) which consists in incorporating a transit marker for a long enough time so that marker excretion equals marker ingestion. Apparent absorption is then determined by comparing nutriment/dietary transit marker ratios in the faeces and at different levels of the digestive tract.

This method was used in 1967 by Ali and Evans to study the effect of lactose on the apparent absorption of calcium. In their experiment, the rats were all killed at the same time of day. Therefore, the results were only valid if the rate of marker and of mineral transit was the same and if apparent absorption remained constant during the light/dark cycle.

To fulfill these two conditions, we studied the effectiveness of $\mathrm{TiO}_{2}$ as a calcium marker on the one hand and changes in the ratio $\mathrm{R}=\frac{\text { mineral }}{\mathrm{TiO}_{2}}$ over a 24-hour period (entire cycle of dietary rhythm) on the other.

TABLE 1

Diet composition $(\%)$

\begin{tabular}{lc}
\hline Maize starch & 58 \\
Casein & 20.5 \\
Maize oil & 9 \\
Cellulose & 5 \\
* Mineral mixture & 4.5 \\
Additional vitamins and aminoacids & 3 \\
\hline
\end{tabular}

The complete diet contained the following mean amounts of minerals (in $\mathrm{mg} / \mathrm{g}$ drymatter) : $\mathrm{Ca}: 7.4, \mathrm{P}: 6.7, \mathrm{Mg}: 0.64$.

* In Andrieux, Sacquet and Guéguen, 1982. 
Finally, because it was impossible to determine if variations in $\mathrm{R}$ were due to variations in apparent absorption, to differences in transit rate between marker and mineral or to chance, we computed the arithmetic mean of all the $R$ values found and their standard deviation. This mean $(\bar{R})$ was used to compute mean apparent absorption $(\bar{A})$ at different levels of the digestive tract (ileum, caecum, colon) for $24 \mathrm{~h}$. Thus, mean apparent absorption $(\overline{\mathrm{A}})$ from ingestion to a level $\mathrm{N}$ of the digestive tract was expressed in $\%$ of ingested matter 1.

$$
\bar{A}(\text { intake }- \text { level } N)=\left(1-\frac{\bar{R} \text { level } N}{\bar{R} \operatorname{diet}}\right) \times 100
$$

The results, expressed as the mean $\pm S D$, were analyzed by the method of Newman and Keuls, modified by Duncan (1955).

Marker effectiveness was checked in experiments 1,2 and 3. Apparent absorption at different digestive tract sites was measured in the various lots in experiment 4.

Experiment 1. - On one night, $4 \mathrm{GF}$ and $4 \mathrm{CV}$ rats received diet $\mathrm{L}$ or LO containing $0.2 \%$ of $\mathrm{TiO}_{2}$ and $0.005 \mu \mathrm{Ci}$ of ${ }^{45} \mathrm{Ca} / \mathrm{g}$ of diet. Daily $\mathrm{TiO}_{2}$ and ${ }^{45} \mathrm{Ca}$ excretions were measured in the faeces for 10 consecutive days.

Experiment 2. - At 4 p.m., $1 \mathrm{GF}$ rat was fed $40 \mathrm{mg}$ of $\mathrm{TiO}_{2}$ and $0.25 \mu \mathrm{Ci}$ of ${ }^{45} \mathrm{Ca}$ in $2 \mathrm{~g}$ of diet $\mathrm{L}$ and $1 \mathrm{GF}$ rat was fed $40 \mathrm{mg}$ of $\mathrm{TiO}_{2}$ and $0.25 \mu \mathrm{Ci}$ of ${ }^{45} \mathrm{Ca}$ in $2 \mathrm{~g}$ of diet LO. Since the rats had been trained previously, they ingested the diets in $10 \mathrm{~min}$ and were then given the diets without the transit marker. The ${ }^{45} \mathrm{Ca} / \mathrm{TiO}_{2}$ ratio was measured in the faeces.

Experiment 3. - For 7 days, $2 \mathrm{CV}$ rats were given diet $L$ containing $0.2 \%$ of $\mathrm{TiO}_{2}$. During this time we measured daily $\mathrm{TiO}_{2}$ excretion. On day 7 , we measured the amounts of $\mathrm{TiO}_{2}$, calcium, magnesium, phosphorus and other minerals in each faecal pellet excreted during the light/dark cycle.

Experiment 4. - For 7 days, $32 \mathrm{GF}$ and $32 \mathrm{CV}$ rats were given either diet $\mathrm{L}$ or LO containing $0.2 \%$ of $\mathrm{TiO}_{2}$. During this time, we measured daily $\mathrm{TiO}_{2}$ excretion. On day 7 , we measured the amounts of $\mathrm{TiO}_{2}$, calcium, magnesium and phosphorus ingested and excreted. On the 8th day, 16 rats of each lot ICVLO, CVL, GFLO, GFL) were killed in pairs every $3 \mathrm{~h}$ for $24 \mathrm{~h}$. We sampled the last $10 \mathrm{~cm}$ of the small intestine, caecum and colon. The digestive contents and faeces of day 7 were homogenized and oven-dried. The $\mathrm{TiO}_{2}$ and minerals were determined from the ash obtained.

Analytical methods. - The $\mathrm{TiO}_{2}$ insoluble in strong acids and bases, was easily separated from the calcium and the other minerals after the samples had been ashed as follows. 100 to $200 \mathrm{mg}$ of dry matter were ashed at $550^{\circ} \mathrm{C}$ for $16 \mathrm{~h}$. This ash was re-dissolved in $10 \%$ hot $\mathrm{HNO}_{3}$ and the insoluble $\mathrm{TiO}_{2}$ was separated from the other minerals by centrifugation at $35000 \times \mathrm{g}$ for $10 \mathrm{~min}$. All the minerals, except $P$, were assayed in the supernatant by atomic absorption spectrometry (apparatus IL151). Phosphorus was assayed by Misson's reaction. The $\mathrm{TiO}_{2}$ was mixed in potassium sulfate acid and dissolved at $100{ }^{\circ} \mathrm{C}$ in $\mathrm{H}_{2} \mathrm{SO}_{4} 2 \mathrm{~N}$. The addition of $\mathrm{H}_{2} \mathrm{O}_{2}$ caused a staining reaction proportional to the 
amount of $\mathrm{TiO}_{2}$. Staining intensity was determined at $410 \mathrm{~nm}$. This method revealed the marker when $10 \mu \mathrm{g}$ or more of it was present.

\section{Results.}

1) Effectiveness of $\mathrm{TiO}_{2}$ as a mineral transit marker.

a) Recovery of ingested $\mathrm{TiO}_{2}$.

Experiment 1. - After the diets containing $0.2 \%$ of $\mathrm{TiO}_{2}$ had been ingested for one night, the recovery rate of the marker (in \% of ingested diet \pm SD for 2 rats per lot) equalled $105.9 \pm 5.0$ (CVLO), $101.2 \pm 3.8$ (CVL), $100.4 \pm 5.2$ (GFLO), $103.4 \pm 2.8$ (GFL) or $102.7 \pm 2.4$ for the 8 rats. This recovery rate was not affected by the type of rat or the diet.

Experiment 2. - The 2 rats receiving $40 \mathrm{mg}$ of $\mathrm{TiO}_{2}$ at a given time excreted 104.5 and $103 \%$, respectively, of the ingested $\mathrm{TiO}_{2}$.

Experiment 4. - On day 7 of the ingestion of $\mathrm{TiO}_{2}$-marked diets, marker recovery rate of the 64 rats averaged $103.0 \pm 1.4 \%$.

b) Comparative transit of $\mathrm{TiO}_{2}$ and ${ }^{45} \mathrm{Ca}$.

Experiment 1. - The patterns of $\mathrm{TiO}_{2}$ and ${ }^{45} \mathrm{Ca}$ excretions were exponential. The ratio of the slopes of the straight lines obtained in semi-logarithmic coordinates averaged $1.001 \pm 0.007$ (means of 8 rats \pm SD).

Experiment 2. - The analysis of each faecal pellet excreted during the excretion of a given dose of $\mathrm{TiO}_{2}$ and ${ }^{45} \mathrm{Ca}$ showed that the ${ }^{45} \mathrm{Ca} / \mathrm{TiO}_{2}$ ratio was constant in the faeces during the light/dark cycle and throughout excretion of the markers (fig. 1).

Experiment 3 (table 2). - - In rats ingesting $\mathrm{TiO}_{2}$ for 7 days, individual analysis of the faecal pellets excreted on day 7 by 2 CVL rats over a 24-hour period showed that the coefficient of variation $\left(\frac{\mathrm{SE}}{\text { mean }} \times 100\right)$ of the ratio $\mathrm{R}\left(\frac{\text { mineral }}{\mathrm{TiO}_{2}}\right)$ was less than $5 \%$ for calcium and less than $10 \%$ for phosphorus, magnesium,

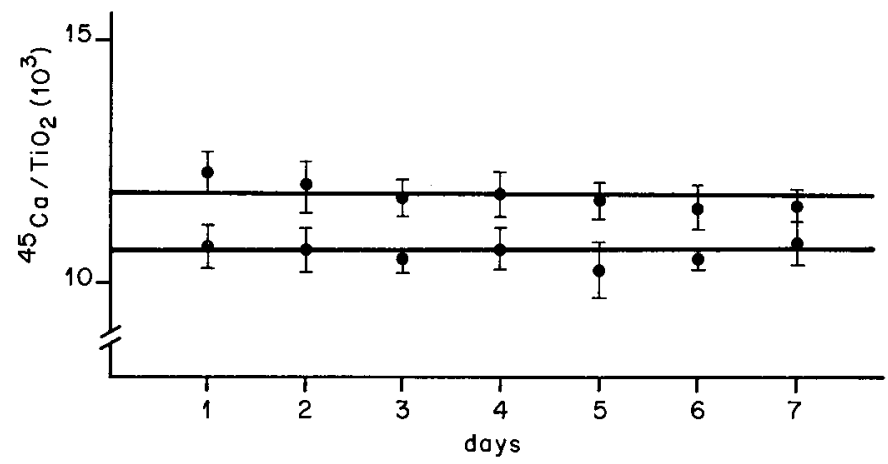

FIG. 1. $-{ }^{45} \mathrm{Ca} / \mathrm{TiO}_{2}$ ratio in the faeces during excretion of a single dose of ${ }^{45} \mathrm{Ca}$ and $\mathrm{TiO}_{2}$. (Each point is the mean of ${ }^{45} \mathrm{Ca} / \mathrm{TiO}_{2}$ of each faecal pellet excreted over $24 \mathrm{~h} \pm \mathrm{SD}$.) 


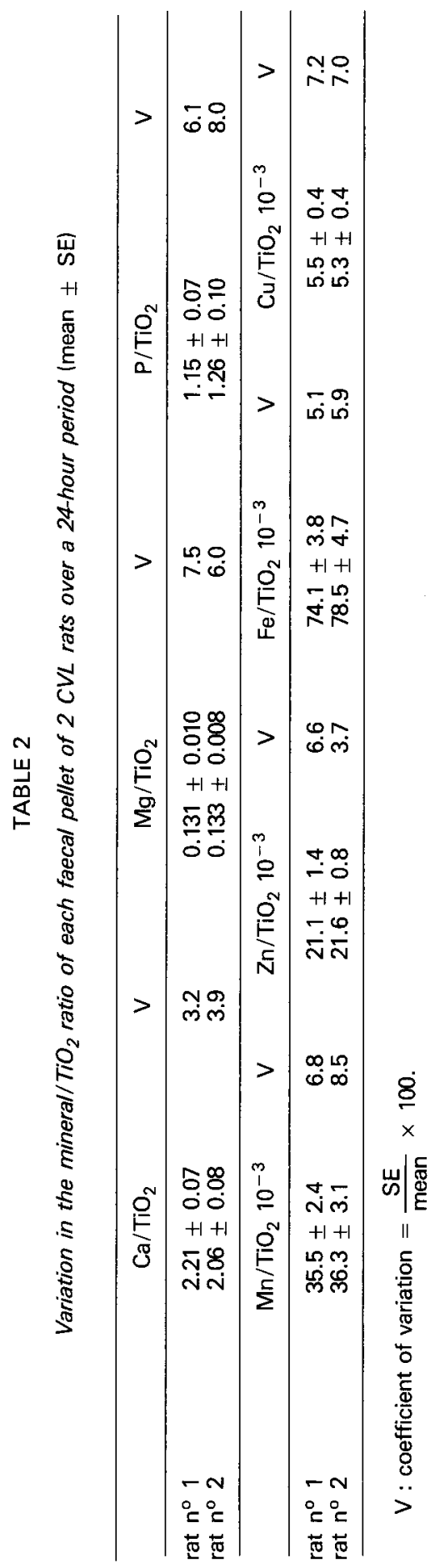


manganese, zinc, iron and copper. These results demonstrate that $\mathrm{TiO}_{2}$ was effective in marking the transit of the unabsorbed minerals.

2) Variations in the $\mathrm{Ca} / \mathrm{TiO}_{2}$ ratio at different levels of the digestive tract during the light/dark cycle (figs. 2, 3, 4, 5) (Experiment 4).

Figures 2 to 5 show the changes in the ratio $\mathrm{R}=\frac{\mathrm{Ca}}{\mathrm{TiO}_{2}}$ at different levels of the digestive tract. In the ileum, the ratio (RI) varied more than in the caecum

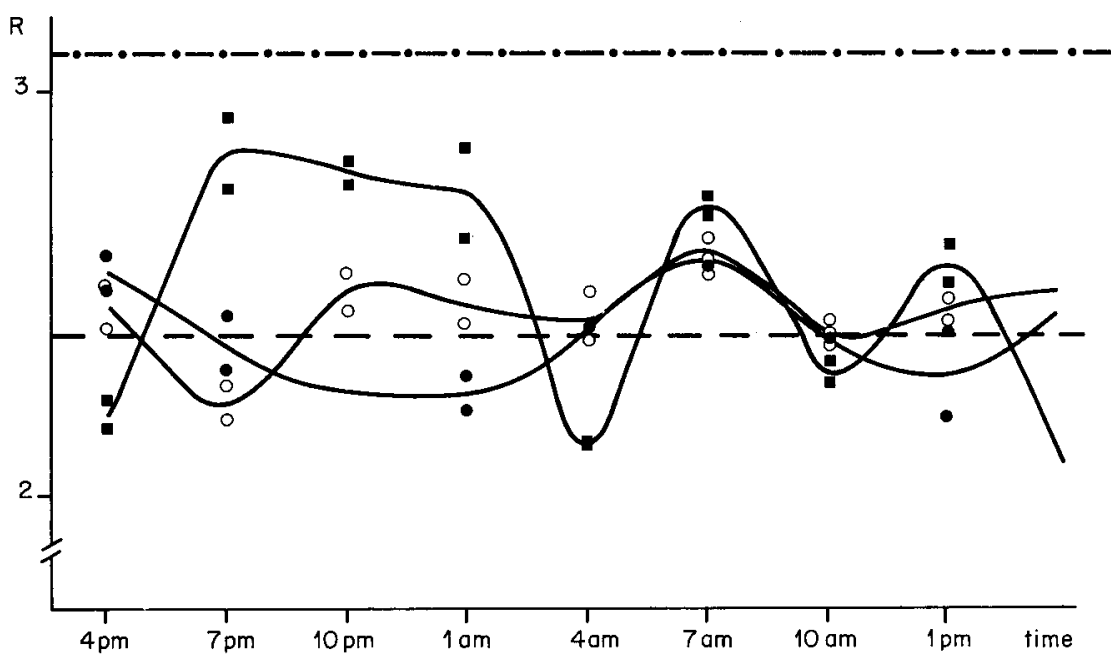

FIG. 2. - Pattern of the $\mathrm{Ca} / \mathrm{TiO}_{2}$ ratio $(R)$ during the light/dark cycle in the ileum $\square$, caecum $\bigcirc$, colon $\bullet$ of $C V L O$ rats. Average value in the diet $\boldsymbol{\bullet}$, average value in the faeces $\mathbf{\square}$

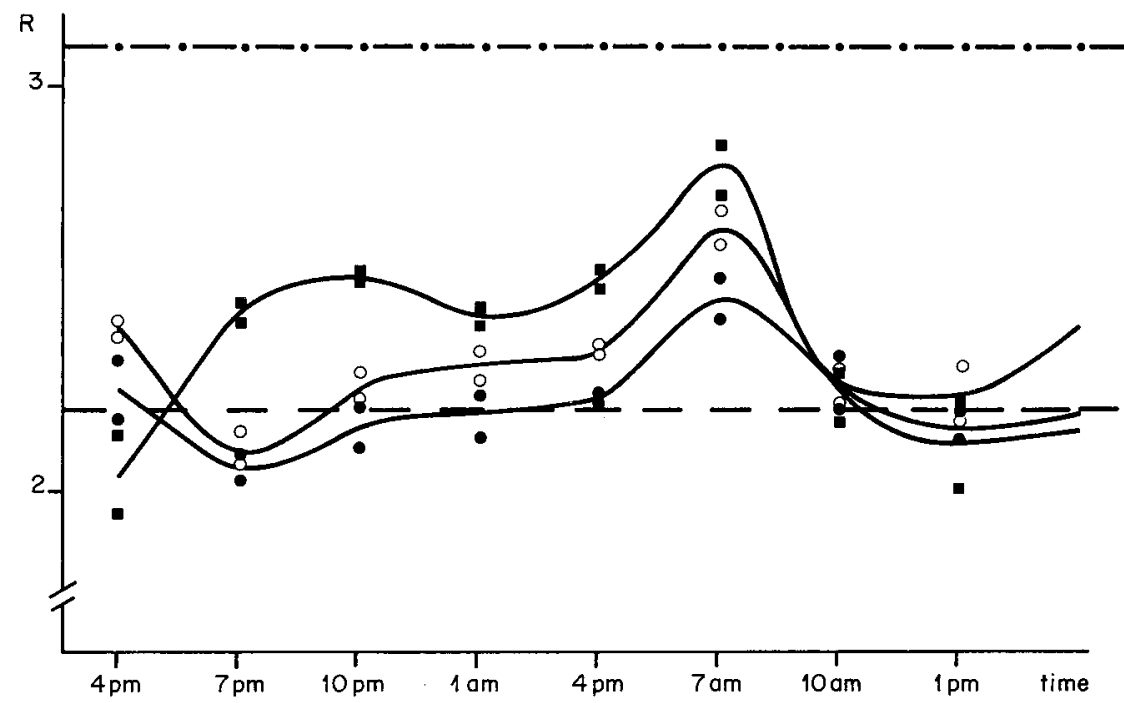

FIG. 3. - Pattern of the $\mathrm{Ca} / \mathrm{TiO}_{2}$ ratio (R) during the light/dark cycle in the ileum $\mathbf{\square}$, caecum $\bigcirc$, colon $\bullet$ of $C V L$ rats. Average value in the diet $\square$. average value in the faeces 
$(\mathrm{RC})$ or colon (RLI) during the light/dark cycle. The highest RI values in all rat lots were found between 7 p.m. and 7 a.m., when diet intake occurred. On the other hand, from 10 a.m. to 4 p.m., low RI values were observed for CVLO, CVL and GFLO rats. In GFL rats, the RI remained constant during almost all the light/dark cycle.

In the caecum, the highest RC values were found at 7 a.m. in $\mathrm{CV}$ rats and at 10 a.m. in GF rats, whether they received lactose or not. However, lactose increased the maximal $\mathrm{RC}$ value of $\mathrm{CV}$ and GF rats.

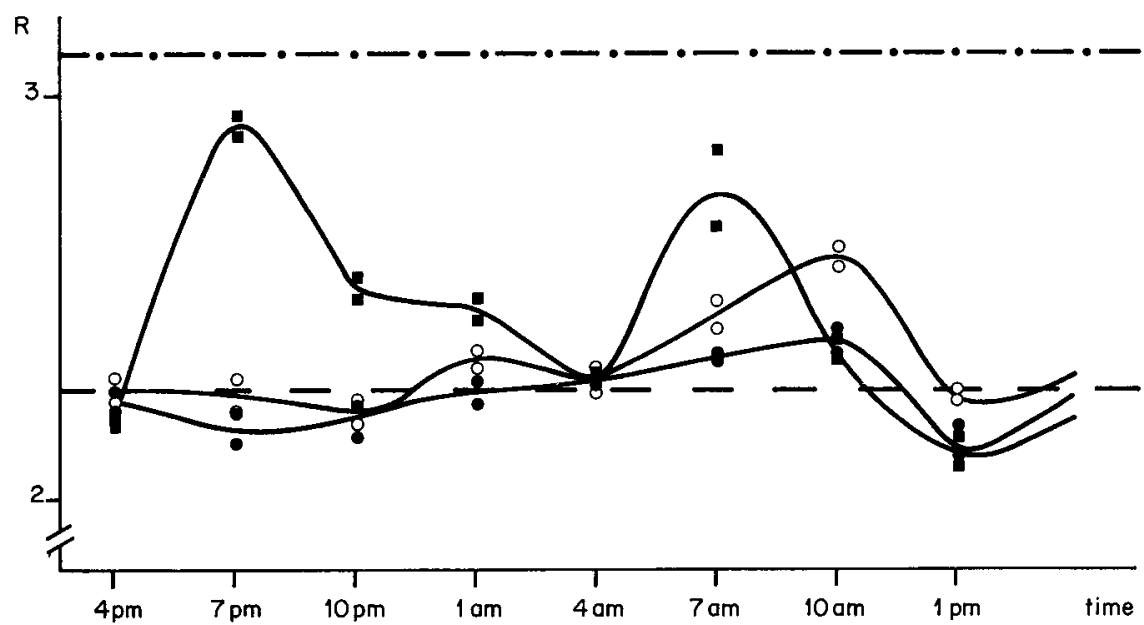

FIG. 4. - Pattern of the $\mathrm{Ca} / \mathrm{TiO}_{2}$ ratio $(R)$ during the light/dark cycle in the ileum $\mathbf{\square}$, caecum $O$, colon - of GFLO rats. Average value in the diet $\boldsymbol{m}$. average value in the faeces $\mathbf{m}$.

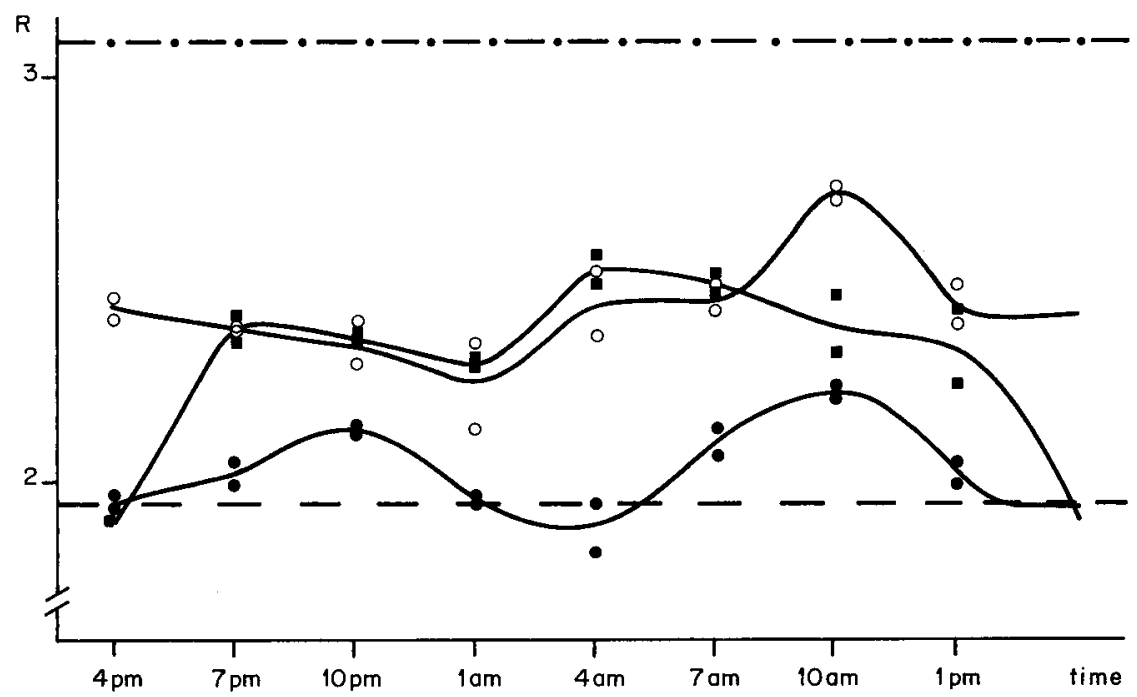

FIG. 5. - Pattern of the $\mathrm{Ca} / \mathrm{TiO}_{2}$ ratio $(R)$ during the light/dark cycle in the ileum caecum $\bigcirc$, colon $\bullet$ of GFL rats. Average value in the diet $\boldsymbol{m}$. average value in the faeces $\mathbf{m}$ 

GF rats.

In the colon, the RLI was also highest at 7 a.m. in CV rats and at 10 a.m. in

The pattern of the $\mathrm{P} / \mathrm{TiO}_{2}$ and $\mathrm{Mg} / \mathrm{TiO}_{2}$ ratios resembled that of the $\mathrm{Ca} / \mathrm{TiO}_{2}$ ratio, i.e. high $\mathrm{RI}$ between 7 p.m. and 7 a.m., maximal $\mathrm{RC}$ at 7 a.m. in $\mathrm{CV}$ rats and at 10 a.m. in GF animals. Variation amplitude depended on the mineral and the site studied.

3) Apparent mineral absorption at different levels of the digestive tract.

Calcium (table 3). - The apparent absorption of calcium from intake to the ileum was comparable in CVLO and GFLO rats. Calcium was not absorbed in the caecum or colon of CVLO rats ; in GFLO rats, calcium absorption was significant in the caecum but not in the colon. Total calcium absorption was comparatively higher in GFLO than in CVLO rats, the difference being in the caecum.

The ingestion of lactose caused a similar increase in calcium absorption in the small intestine of both $\mathrm{CV}$ and GF rats. Lactose had no significant effect in the caecum or colon in $\mathrm{CV}$ rats. High calcium absorption was found in the colon of GF animals. Thus, lactose had a much stronger effect on total calcium absorption in GF than in $\mathrm{CV}$ rats.

Phosphorus (table 4). - The rate of phosphorus absorption from intake to the ileum was higher in GFLO than in CVLO rats. In the latter, this absorption

\section{TABLE 3}

\section{Apparent absorption of calcium (in \% of intake) from intake to ileum, caecum and colon and total apparent absorption \\ ( $n=16$ per lot) (mean \pm SD)}

\begin{tabular}{lcccc}
\hline Rats and Diet & \multicolumn{1}{c}{ CVLO } & CVL & GFLO & GFL \\
\hline Intake-ileum & $19.0 \pm 10.5^{\mathrm{d}}$ & $23.7 \pm 9.2^{\mathrm{bc}}$ & $19.7 \pm 8.7^{\mathrm{d}}$ & $26.0 \pm 6.4^{\mathrm{bc}}$ \\
Intake-caecum & $21.0 \pm 4.2^{\mathrm{d}}$ & $25.5 \pm 5.2^{\mathrm{bc}}$ & $24.5 \pm 4.1^{\mathrm{bc}}$ & $22.2 \pm 5.2^{\mathrm{cd}}$ \\
Intake-colon & $22.9 \pm 5.2^{\mathrm{cd}}$ & $28.7 \pm 4.8^{\mathrm{b}}$ & $27.4 \pm 2.9^{\mathrm{b}}$ & $35.5 \pm 4.2^{\mathrm{a}}$ \\
Intake-faeces (total apparent & $22.6 \pm 3.5^{\mathrm{cd}}$ & $28.4 \pm 2.9^{\mathrm{b}}$ & $27.7 \pm 1.6^{\mathrm{b}}$ & $37.4 \pm 2.9^{\mathrm{a}}$ \\
absorption) & & & &
\end{tabular}

Values with the same script were not significantly different at $5 \%$ according to the NewmanKeuls test.

TABLE 4

Apparent absorption of phosphorus (in \% of intake) from intake to ileum, caecum and colon and total apparent absorption

$(\mathrm{n}=16$ per lot $)($ mean $\pm \mathrm{SD})$

\begin{tabular}{lcccc}
\hline Rats and Diet & CVLO & CVL & GFLO & GFL \\
\hline Intake-ileum & $34.4 \pm 11.4^{\mathrm{d}}$ & $50.1 \pm 9.3^{\mathrm{bc}}$ & $48.7 \pm 12.0^{\mathrm{bc}}$ & $54.1 \pm 11.4^{\mathrm{b}}$ \\
Intake-caecum & $47.7 \pm 5.4^{\mathrm{c}}$ & $52.7 \pm 3.2^{\mathrm{b}}$ & $53.4 \pm 5.0^{\mathrm{b}}$ & $56.3 \pm 4.7^{\mathrm{b}}$ \\
Intake-colon & $46.9 \pm 5.7^{\mathrm{c}}$ & $54.8 \pm 2.1^{\mathrm{b}}$ & $54.0 \pm 3.6^{\mathrm{b}}$ & $61.6 \pm 4.3^{\mathrm{a}}$ \\
$\begin{array}{l}\text { Intake-faeces (total apparent } \\
\text { absorption) }\end{array}$ & $47.6 \pm 3.4^{\mathrm{c}}$ & $53.0 \pm 2.5^{\mathrm{b}}$ & $53.0 \pm 3.5^{\mathrm{b}}$ & $61.2 \pm 1.8^{\mathrm{a}}$
\end{tabular}

Values with the same script were not significantly different at $5 \%$ according to the NewmanKeuls test. 
was significant in the caecum but it was not significant in GFLO animals. Total phosphorus absorption, however, was higher in the GFLO than in the CVLO rats.

The ingestion of lactose diets increased phosphorus absorption more in the small intestine of $\mathrm{CV}$ than of GF rats, and thus the rate of phosphorus absorption was comparable to that in the ileum of CVL and GFL rats.

Rats fed lactose did not absorb a significant amount of phosphorus in the caecum. Phosphorus absorption in the colon was higher in GFL than in CVL rats.

Total phosphorus absorption was augmented by lactose in both $\mathrm{CV}$ and GF rats. In CV animals, lactose had an effect in the small intestine, while in GF rats that effect was in the hindgut.

Magnesium (table 5). - In CVLO and GFLO rats, apparent absorption of magnesium from intake to the ileum was similar. In the caecum, apparent absorption of magnesium was significant in both CVLO and GFLO rats, but was higher in the latter. No significant absorption was found in the colon of either CVLO or GFLO rats. Total magnesium absorption was much higher in GFLO than in CVLO animals, the difference being entirely due to better magnesium absorption in the caecum of GFLO rats.

\section{TABLE 5}

Apparent absorption of magnesium (in \% of intake) from intake to ileum, caecum and colon and total apparent absorption

( $\mathrm{n}=16$ per lot) (mean $\pm \mathrm{SD})$

\begin{tabular}{lcccc}
\hline Rats and Diet & CVLO & CVL & GFLO & GFL \\
\hline Intake-ileum & $26.1 \pm 7.5^{\mathrm{e}}$ & $45.0 \pm 14.0^{\mathrm{d}}$ & $27.1 \pm 2.1^{\mathrm{e}}$ & $41.1 \pm 7.6^{\mathrm{d}}$ \\
Intake-caecum & $42.5 \pm 6.6^{\mathrm{d}}$ & $5.7 \pm 8.4^{\mathrm{c}}$ & $64.1 \pm 4.5^{\mathrm{b}}$ & $63.1 \pm 5.9^{\mathrm{b}}$ \\
Intake-colon & $45.6 \pm 8.4^{\mathrm{d}}$ & $59.5 \pm 5.6^{\mathrm{bc}}$ & $66.2 \pm 3.8^{\mathrm{b}}$ & $72.5 \pm 5.9^{\mathrm{a}}$ \\
Intake-faeces (total apparent & $43.9 \pm 4.2^{\mathrm{d}}$ & $57.4 \pm 4.5^{\mathrm{c}}$ & $63.0 \pm 4.1^{\mathrm{b}}$ & $72.8 \pm 3.1^{\mathrm{a}}$ \\
absorption) & & & &
\end{tabular}

Values with the same script were not significantly different at $5 \%$ according to the NewmanKeuls test.

In the small intestine, lactose caused a similar increase in apparent absorption of magnesium in both $\mathrm{CV}$ and GF rats. Magnesium absorption was significantly higher in the caecum of GFL than CVL animals. However, absorption in the caecum increased less in those fed lactose diets (CVL, GFL) than in those fed the lactose-free diets (CVLO, GFLO). In the colon, magnesium absorption was only increased in GFL rats. The favorable effect of lactose on total magnesium absorption was essentially evidenced in the small intestine.

\section{Discussion.}

That $\mathrm{TiO}_{2}$ seemed to be effective as a transit marker of unabsorbed minerals is shown by the constant $R$ in each faecal pellet. The variations in this ratio at different levels of the digestive tract contrast with the constant value found in 
the faeces. However, $R$ shows similar values in the two animals of each experimental group killed at the same time. Therefore, these variations are not due to chance. Moreover, the curves are similar in the various experimental lots, suggesting that variations in $\mathrm{R}$ are related to a dietary rhythm in rat, as described by Lutton and Chevallier (1973). These variations are more accentuated in the ileum than in the caecum and colon. The low values in the ileum correspond to the longest times after the meal and, on the contrary, the high values to times of digestion. The largest variations found in the ileum were certainly related to the fact that the ileum empties and fills more quickly than the caecum and colon. However, we could not determine the origin of $R$ variations. Would they be due to slight differences in the transit rate of the marker and the mineral which, when measured in the faeces, revealed nothing, or, on the contrary, would they result from variations in the rate of absorption and secretion, of which only apparent absorption was measured by the method we used ?

This question led us to consider the arithmetic value of $R$ and its standard deviation, a process that penalizes the estimate and measures only important variations in apparent absorption. The existence of $\mathbf{R}$ variability in relation to time demonstrates that it is necessary to carry out observations during the whole light/dark cycle and that measuring only at a given time is hazardous.

The analysis of the results showed that the effects of microflora and lactose vary with the mineral and the digestive tract level studied. (Reddy (1971, 1972) reported that the mucosa of GF rats was much richer in $\mathrm{Mg}$ and $\mathrm{Ca}$-dependent ATPases, alkaline phosphatase and $\mathrm{CaBP}$, and proposed that this could explain the better absorption of calcium, phosphorus and magnesium in GF rats. Our results do not confirm this. They show that calcium and magnesium absorption was comparable in the small intestine of $\mathrm{CV}$ and GF rats. In the caecum of GFLO rats, significantly higher quantities of calcium and magnesium were absorbed than in CVLO rats. The factor contributing to better calcium and magnesium absorption in GF rats may be a voluminous caecum, a higher amount of soluble calcium (Andrieux, Sacquet and Guéguen, 1982) and a much longer transit time (Sacquet, Garnier and Raibaud, 1970).

Apparent absorption of calcium in the caecum of CV rats is usually low (Marcus and Lengemann, 1962 ; Urban, 1971). Some studies have shown a balance between true absorption and calcium secretion in the caecum (Petith and Schedl, 1976 ; Harrison and Harrison, 1969 ; Favus et al., 1980 ; Favus, Kathpalia and Coe, 1981 ; Lee et al., 1980). The present study agrees with the results of Cramer (1951) who reported significant phosphorus absorption in the terminal intestine of $\mathrm{CV}$ rats. The site of magnesium absorption is not well known ; our results show that the terminal intestine plays an important role in its absorption. The increase in caecal size and transit time appears to favor this absorption. GF rats have higher magnesium absorption in the caecum than $\mathrm{CV}$ rats. The ingestion of potato starch considerably increases the caecal volume of $\mathrm{CV}$ rats and also increases magnesium absorption (Rayssiguier and Rémésy, 1977).

The effect of lactose on calcium absorption in the small intestine confirms other work on this subject (Wasserman and Taylor, 1976; Armbrecht and 
Wasserman, 1976) : our results demonstrate that magnesium absorption is considerably increased by lactose. At this digestive level, the effect of lactose on the absorption of these minerals is comparable in $\mathrm{CV}$ and GF rats. In the hindgut, the effect of lactose is different in the two types of rat. These differences seem to be due to the fact that lactose is hydrolized by microflora in CVL but not in GFL rats. Various experiments point to the effect of undigestible carbohydrates on mineral absorption in the caecum or the rumen (Rayssiguier and Rémésy, 1977 ; Demigné, Rémésy and Rayssiguier, 1980 ; Rayssiguier and Poncet, 1980). Our study did not evidence such an effect. These divergences may be due to different experimental conditions and particularly to the low lactose content of our diets. However, $10 \%$ of lactose in the diet did modify mineral absorption in the small intestine.

In the hindgut of GF rats, lactose had a favorable effect on mineral absorption in the colon but not in the caecum, as we hypothesized previously (Andrieux, Sacquet and Guéguen, 1982).

Is the action mechanism of lactose in the colon comparable to that in the small intestine? This question is difficult to answer because we studied only apparent digestion and not secretion and absorption as such. The action of each of these processes must be determined in these various experimental groups, as has been done in conventional rat by Favus, Kathapalia and Coe (1981). Variations in alkaline phosphatase, suggested by Fournier and Dupuis to be implicated in the effect of lactose in the ileum (Dupuis, Fournier and Fournier, 1976 ; Dupuis, Digaud and Fournier, 1978), must also be studied. Fair amounts of this enzyme are present in the colon of germfree and conventional rats (Kawai and Morotomi, 1978).

Reçu en juillet 1982.

Accepté en novembre 1982.

Résumé. Effet de la flore et du lactose sur l'absorption du calcium, du phosphore et du magnésium au niveau de l'intestin terminal du rat.

Des rats axéniques et holoxéniques, âgés de trois mois, reçoivent pendant 4 semaines, un aliment semi-synthétique stérilisé par irradiation, contenant ou non $10 \%$ de lactose. Pendant la $5^{e}$ semaine, $0,2 \%$ d'oxyde de titane est ajouté à l'aliment. Les rats sont alors sacrifiés à intervalle régulier pendant un nycthémère. L'excrétion comparée de l'oxyde de titane et du ${ }^{45} \mathrm{Ca}$ est très semblable, ce qui conduit à penser que cette substance constitue un bon marqueur du transit du calcium non absorbé. L'étude du rapport minéral/oxyde de titane au niveau de l'iléon, du caecum, du gros intestin et des matières fécales permet de déterminer l'absorption apparente du calcium, du magnéșium et du phosphore à ces différents niveaux. La flore et le lactose ont des effets différents selon le minéral et le niveau du tractus digestif considérés.

- Au niveau de I'intestin grêle : la flore n'a pas d'effet sur l'absorption apparente du calcium et du magnésium, elle a un effet défavorable sur l'absorption du phosphore. Le lactose augmente l'absorption du calcium et du magnésium de manière semblable chez les rats holoxéniques et axéniques. II a un effet favorable sur l'absorption du phosphore chez les seuls rats holoxéniques.

- Au niveau du caecum; la flore a un effet défavorable sur l'absorption apparente du calcium et du magnésium, elle a un effet favorable sur celle du phosphore. L'ingestion de lactose réduit l'absorption du calcium et du magnésium au niveau du caecum des rats axéniques, et celle du phosphore au niveau du caecum des rats holoxéniques. 
- Au niveau du côlon : les minéraux ne sont pas significativement absorbés chez les rats holoxéniques et axéniques qui ne reçoivent pas de lactose. L'ingestion de lactose provoque une augmentation significative de l'absorption de calcium de magnésium et de phosphore chez les seuls rats axéniques. Cette absorption est responsable de l'effet plus important du lactose sur l'absorption totale du calcium et du phosphore chez les rats axéniques comparés aux rats holoxéniques.

\section{References}

ALI R., EVANS J. L., 1967. Effect of dietary calcium, buffering capacity, lactose and EDTA on pH of and calcium absorption from gastrointestinal segments in the growing rat. J. Nutr., 93, 273-279.

ANDRIEUX C., SACQUET E., GUÉGUEN L., 1982. Microbial flora in the digestive tract and action of lactose on mineral metabolism. Reprod. Nutr. Dévelop., 22, 387-394.

ARMBRECHT H. J., WASSERMAN R. H., 1976. Enhancement of $\mathrm{Ca}^{++}$uptake by lactose in the rat small intestine. J. Nutr., 106, 1265-1271.

CRAMER C. F., 1961. Progress and rate of absorption of radiophosphorus through the intestinal tract of rats. Can. J. Biochem. Physiol., 39, 409-503.

DEMIGNÉ C., REMÉSY C., RAYSSIGUIER Y., 1980. Effect of fermentable carbohydrates on volatile fatty acids, ammonia and mineral absorption in the rat caecum. Reprod. Nutr. Dévelop., 20, 1351-1360.

DUCAN D. B., 1955. Multiple range and multiple $F$ tests. Biometrics, 11, 1-42.

DUPUIS Y., DIGAUD A., FOURNIER P., 1978. Phosphatases alcalines intestinales et composés glucidiques dans leurs rapports avec l'absorption du calcium. Ann. Biol. anim. Bioch. Biophys., 18, 1129-1139.

DUPUIS Y., FOURNIER A., FOURNIER P., 1976. Etude, au niveau de la muqueuse jéjunale, des effets de divers composés glucidiques sur l'activité de quelques enzymes localisées dans les bordures en brosses. Accroissement d'activité phosphatasique. C.R. Soc. Biol., 170. 739-744.

FAVUS M. J., KATHPALIA S. C., COE F. L., 1981. Kinetic characteristics of calcium absorption and secretion by rat colon. Am. J. Physiol., 240 (Gastrointest. Liver Physiol. 3) : G350-G354.

FAVUS M. J., KATHPALIA S. C., COE F. L., MOND A. E., 1980. Effects of diet calcium and 1,25-dihydroxyvitamin $D_{3}$ on colon calcium active transport. Am. J. Physiol., 238 (Gastrointest. Liver Physiol. 1) : G75-G78.

FOURNIER P., 1950. De l'emploi de l'oxyde de titane pour l'étude quantitative de l'absorption intestinale. C.R. Acad. Sci. Paris, 226, 1343-1345.

HARRISON H. C., HARRISON H. E., 1969. Calcium transport by rat colon in vitro. Am. J. Physiol., 217, 121-125.

KAWAI Y., MOROTOMI M., 1978. Intestinal enzyme activities in germfree, conventional and gnotobiotic rats associated with indigenous microorganisms. Infect. Immun., 19, 771-778.

KOTB A. R., LUCKEY T. D., 1972. Markers in nutrition. Nutr. Abstr. Rev., 42, 813-845.

LEE D. B. N., WALLING M. W., GAFTER U., SILIS V., COBURN J., 1980. Calcium and inorganic phosphate transport in rat colon. J. clin. Invest., 65, 1326-1331.

LUTTON C., CHEVALLIER F., 1973. Coprophagie chez le rat blanc. Aspects quantitatifs et relation chronologique avec les prises alimentaires. J. Physiol., Paris, 66, 219-228.

MARCUS C. S., LENGEMANN F. W., 1962. Absorption of $\mathrm{Ca}^{45}$ and $\mathrm{Sr}^{85}$ from solid and liquid food at various levels of the alimentary tract of the rat. J. Nutr., 77, 155-160.

PETITH M. M., SCHEDL H. P., 1976. Intestinal adaptation to dietary calcium restriction : in vivo cecal and colonic calcium transport in the rat. Gastroenterology, 71, 1039-1042.

RAYSSIGUIER Y., PONCET C., 1980. Effect of lactose supplement on digestion of lucerne hay by sheep. II. Absorption of magnesium and calcium in the stomach. J.anim. Sci., 51, 186-192.

RAYSSIGUIER Y., REEMÉSY C., 1977. Magnesium absorption in the caecum of rats related to volatile fatty acid production. Ann. Rech. vét., 8, 105-110. 
REDDY B. S., 1971. Calcium and magnesium absorption : role of intestinal microflora. Fed. Proc., 30, $1815-1821$.

REDDY B. S., 1972. Studies on the mechanism of calcium and magnesium absorption in germfree rats. Arch. Bioch. Biophys., 149, 15-21.

SACOUET E., GARNIER H., RAIBAUD P., 1970. Etude de la vitesse du transit gastro-intestinal des spores d'une souche thermophile stricte de Bacillus subtilis chez le rat " holoxenique ", le rat "axénique ", le rat " axénique " caecectomisé. C.R. Acad. Sci. Paris, 164, 532-537.

URBAN E., 1971. The colon and calcium homeostasis in the rat (abstr.) Gastroenterology, 60, 728.

WASSERMAN R. H., TAYLOR A. N., 1976. Intestinal absorption of calcium, 379-393. In COMAR C. L., BRONNER F., Mineral metabolism Vol. V. Acad. Press, New York. 